Of de activa, die voor de publieke dienst bestemd zijn, echter op zoveel of zoveel milliarden guldens worden getaxeerd, - een taxatie, welke practisch onmogelijk is - , is een wetenschap, die de duizenden guldens, die het kost om de taxaties te verrichten, niet waard is. Tenzij er andere, niet-economische, argumenten zijn, is de taxatie overbodig werk.

\title{
ANDERE OPMERKINGEN OVER MOGELIJKHEDEN EN WENSE- LIJKHEDEN VAN EEN VERBIZONDERING IN DE UITOEFENING VAN HET ACCOUNTANTSBEROEP
}

doot A. M, van Rietschoten

Het in het October-nummer verschenen artikel van prof. Van der Schroeff houdt een uitnodiging in, die naar mijn mening behoort te worden aanvaard, n.l. om bijdragen te leveren tot de discussie over het differentiatie-vraagstuk in ons beroep, zonder daaraan te verbinden, dat reeds de formulering van een conclusie zou zijn te verwachten. Tot een gezette voorbereiding van dit laatste heeft het N.I.v.A. een studiecommissie ingesteld, welker oordeel ten deze in de eerste plaats zou moeten worden gehoord.

Het is van grote waarde in deze discussie te worden geleid door een systematisch betoog, zoals dat door prof. Van der Schroeff is gegeven,

en ik vind daarin dan ook de vrijheid omtrent enige elementen in dat betoog een enkele opmerking te maken. Moge ik mijnerzijds de minzame mededeling van prof. Van der Schroeff, dat in hetgeen door hem is gesteld geen critiek moet worden gezien op de beroepsuitoefening der practiserende accountants. reciproceren met het verzoek in mijn opmerkingen zelfs geen poging te zien tot aanmerkingen op het door hem gegeven betoog. Vele mijner collega's zullen met mij zeer veel waardering hebhen voor hetgeen daarin is gesteld en voor de wijze waarop het is geformuleerd.

Mijn opmerkingen bedoelen niet anders te zijn dan elementen in het beraad, dat ten aanzien van dit vraagstuk van het beroep wordt gevraagd.

Duidelijk spreken uit het opstel van prof. Van der Schroeff twee fundamentele argumenten resp. tegen de specialisatie in het beroep naar de bedrijfstakken en voor een mogelijke differentiatie tot een afzonderlijke adviserende functie.

Deze argumenten zijn daarom van zo groot gewicht te achten, omdat ze zijn ontleend aan de erkende grondslagen voor het beroep. Ik moge $z \in$ als volgt kort weergeven: tegen de specialisatie van het beroep naar de bedrijfstakken, waartoe de bedrijfshuishoudingen behoren te wier aanzien de functie zal worden vervuld, bestaat het bezwaar, dat het ten volle nakomen van de geheimhoudingsplicht in het gedrang komt.

Ik moge hier terloopt bij opmerken, dat dit bezwaar niet gericht is tegen een specialisatie in de contrōlerende functie maar tegen de consequenties van de specialisatie in de adviserende functie, zodat, indien een differentiatie van de adviserende functie wordt overwogen, bij voorbaat zal vaststaan, dat in dat gedifferentieerd beroep nog in sterker mate geen plaats kan zijn voor specialisatie naar bedrijfstakken.

Voor het overwegen van het afsplitsen van de adviserende functie 
wordt als het meest fundamenteel argument het volgende naar voren gebracht.

Bij de gecombineerde vervulling van de controlerende en de adviserende functie moeten, omderwille van het behoud van de objectiviteit, nodig voor de vervulling van de controlerende functie, vrij aanmerkelijke beperkingen in het adviserend werk worden aanvaard.

De onderwerpen, waaromtrent adviezen worden gevraagd en gegeven, zullen onderzocht moeten worden op de vraag of ten aanzien daarvan het genoemde bezwaar moet gelden. Maar daarnaast moet onder ogen worden gezien of het adviserend werk met succes kan worden vervuld door dengene, die zich van het afgeven van accountantsverklaringen onthoudt.

Wanneer voor de afsplitsing van de adviserende functie naar een afzonderlijk beroep als belangrijk'argument zal gelden, dat een uit de controlerende functie voortkomende beperking wordt opgeheven, moet onder ogen worden gezien, dat die differentiatie dan een volkomene moet zijn. $\mathrm{lk}$ bedoel daarmede, dat de beroepsadviseur niet alleen niet ten aanzien van de bedrijfshuishoudingen te wier behoeve hij als adviseur fungeert, doch tevens ten aanzien van andere bedrijfshuishoudingen, geen accountantsverklaringen moet resp. mag afgeven. In de eerste plaats vraagt het handhaven van de nodige objectiviteit een geesteshouding, welke niet toelaat ze van tijd tot tijd te verlaten. Maar bovendien mag het verkeer niet worden blootgesteld aan de noodzaak tot het maken van onderscheidingen of aan de verklaring van een adviserend functionaris een andere (in sommig opzicht lagere) betekenis moet worden toegekend, dan aan die van een controlerend functionaris.

Ik meen zelfs, dat als een afsplitsing van de adviserende functie zodanige voordelen zal blijken te hebben, dat zij tot stand komt, er ernstige bezwaren tegen bestaan, dat het adviserend beroep met de naam accountant zal worden aangeduid.

De meest specifieke functie, het afgeven van verklaringen, zal door de beroepsadviseur niet worden vervuld en daarmede zal zijn plaats in het maatschappelijk verkeer niet die van vertrouwensman van dat verkeer kunnen zijn; dit kome in de beroepsaanduiding dan duidelijk tot uitdrukking.

Welke beperkingen kunnen nu weer voor de uitoefening van het afgesplitste adviseursberoep verbonden zijn aan het niet fungeren als vertrouwensman van het maatschappelijk verkeer? Ik vind gerede aanleiding om deze vraag op te werpen in de mening van prof. Van der Schroeff (pag. 290), dat tot de omstandigheden, welke belangrijke toeneming van het adviserend werk hebben veroorzaakt, gerekend moeten worden de problemen, welke de bedrijven worden gesteld, door de overheidsmaatregelen op economisch gebied. Een uitgebreid en veelzijdig terrein is het waarop die overheidsmaatregelen betrekking hebben; maar zie ik het goed, dan is belangrijker dan het te verrichten adviserend werk, dat de accountant in het contact van de bedrijven met de overheid, kan optreden met het aanvaarde gezag, dat zijn controlerende functie hem verleent. Alleen zijn onverdachte objectiviteit kan hem dit gezag verlenen en doen behouden. Een op grond van lager te stellen objectiviteitseisen fungerend adviseur zal dit gezag terecht niet hebben.

Tenslotte zou ik nog een vraagstuk van algemene aard naar voren willen brengen.

In hoeverre kan verwacht worden, dat de bedrijfsleiding blijvend be- 
hoefte zal hebben aan bedrijfseconomisch advies van zodanigen aard, dat de verenigbaarheid met de controlerende functie van de accountant verworpen moet worden. In het algemeen zullen dat adviezen moeten $z$ ijn over vraagstukken in het bijzonder liggende op het terrein van de dirigerende, ja veelal de constituerende leiding. Vraagstukken welker beslissing als regel beheersdaden van groot belang zijn. Welnu, wat wordt het organisatorisch beeld, wanneer die beslissingen moeten worden genomen aan de hand van adviezen, zó, dat de beslissing genomen, de adviseur nog een verantwoordelijkheid voor de gevolgen van die beslissing zou blijven meedragen. I $k$ zie dan toch een tekortschieten van de leiding.

Dat onder de gegeven, naar ik meen bijzondere, omstandigheden in vele bedrijfshuishoudingen een overbezetting van de leiding is opgetreden, is onmiskenbaar. Een daardoor omvangrijker beroep op adviseurs, gedeeltelijk tredende in de plaats van de leiding, is een noodmaatregel, waarvan de leiding op de duur niet ongestraft gebruik kan maken, terwijl de adviseur niet ongestraft gehoor zal kunnen blijven geven aan verzoeken van die strekking.

Dat de overheid harerzijds te kampen heeft met een overbezetting van zijn leiginggevend apparaat en daardoor van tijd tot tijd ook een beroep doet op de hulp van adviseurs, wier adviezen worden gevolgd, zonder dat over de inhoud dier adviezen voldoende critisch beraad en daarna verantwoord besluit wordt genomen, acht ik mogelijk en zelfs waarschijnlijk.

Maar deze verschijningsvormen zullen toch van voorbijgaande aard moeten blijken.

En op welke gronden zou van het afgesplitste adviseursberoep de doelmatigheid moeten worden verwacht?

Voor de vraagstukken, die er voor hem liggen zouden bij de grote bedrijfseenheden (meer in het bijzonder de grote ondernemingen), is een zodanig omvangrijke kennis nodig van het bedrijf (of de bedrijven), dat een eigen orgaan van de leiding, voorzien van de nodige deskundigheid, aan de oplossing van deze vraagstukken zal worden gezet.

En bij de middelgrote? Zal daar veelal de leiding niet in staat zijn, zelfs in staat mòèten zijn, deze vraagstukken zelf op te lossen? Er moet een grens zijn, waarbij de onvoldoende capaciteit van de leiding irrationeel wordt; waar ligt die?

Het is dunkt mij aan de bedrijfseconomie de analyse van dit probleem te geven.

\section{UIT HET BUITENLAND}

Internationale samenwerking tussen accountants.

(International Cooperation among Accountants).

Artikel in ,The Journal of Accountancy". December 1947.

In een toespraak tijdens de jaarlijkse vergadering van het American Institute of Accountants in October 1946, gaf Sir Harold Howitt, voorzitter van het Institute of Chartered Accountants in England en Wales. als zijn mening, dat er over de gehele wereld meerdere samenwerking moet zijn tussen de Accountants-Verenigingen.

Deze suggestie leidde tenslotte tot een vergadering van vertegenwoordigers van het Institute of Chartered Accountants, the Dominion Association of Chartered Accountants (Canada) en het American Insti-

$\mathrm{m}$ a b blz. 60 